P-ISSN $2580-7781$

E-ISSN 2615 - 3238

\title{
ANALISIS KEBIJAKAN POLITIK LUAR NEGERI INDONESIA SEBAGAI MEDIATOR KONFLIK ANTARA ARAB SAUDI DENGAN IRAN TAHUN 2016
}

\section{ANALYSIS OF INDONESIAN OVERSEAS POLITICAL POLICY AS A CONFLICT MEDIATOR BETWEEN SAUDI ARABIA WITH IRAN IN 2016}

\author{
Lila Agustin Triana Sari ${ }^{1)}$, Pipin Nabila ${ }^{2)}$, Depict Pristine Adi ${ }^{3)}$ \\ ${ }^{1,2,3}$ Tadris Ilmu Pengetahuan Sosial, Fakultas Tarbiyah Dan Ilmu Keguruan, IAIN Jember \\ Email : ${ }_{1}^{1}$ lilaagustin5@gmail.com
}

\begin{abstract}
ABSTRAK
Tujuan dari penelitian ini adalah untuk mengetahui peran Indonesia sebagai mediator dalam mendamaikan konflik Arab Saudi dengan Iran pada tahun 2016. Wilayah Timur Tengah dapat dipahami sebagai wilayah yang rentang dengan banyak konflik. Adanya konflik diwilayah Timur Tengah yang semakin meningkat sehingga perlu cara konstruktif serta berkelanjutan guna meminimalisir berkembangnya konflik. Diantaranya yang menjadi sorotan komunitas internasional yaitu semakin memuncaknya konflik pasca ditetapkan hukuman mati oleh Arab Saudi terhadap ulama besar Iran Syekh Nimr AlNimr. Melihat kondisi memanas diwilayah Timur Tengah, Indonesia menawarkan diri untuk ikut serta dalam mendamaikan konflik kedua negara tersebut. Lebih lanjut permasalahan ini dianalisis dengan menggunakan teori konflik, mediasi dan kepentingan nasional. Dalam penelitian ini menggunakan metode Studi Pustaka (Library Research) dengan penyajian data secara deskriptif. Studi Pustaka yang dimaksud pada penelitian ini adalah dengan mengumpulkan data dari lapangan seperti buku, jurnal, laporan hasil penelitian, website dan lain sebagainya yang memiliki informasi relevan dengan topik penelitian. Berdasarkan hasil pembahasan dapat disimpulkan bahwa keterlibatan Indonesia yang memiliki hubungan baik terhadap kedua negara tersebut yaitu untuk membantu upaya penyelesaian konflik secara damai agar tidak berpengaruh besar terhadap negara-negara tetangga. Alasan Indonesia terlibat sebagai mediator konflik antara Arab Saudi dan Iran karena mendapat dukungan dari dalam negeri yang didukung oleh Majelis Ulama Indonesia (MUI) dan terdapat beberapa kepentingan nasional seperti kepentingan ekonomi dan kepentingan sosial terhadap kedua negara tersebut.
\end{abstract}

Kata Kunci : Konflik, Arab Saudi, Iran, Indonesia, Mediator

\section{ABSTRACT}

The purpose of this study is to find out the role of Indonesia as a mediator in reconciling Saudi Arabia's conflict with Iran in 2016. The Middle East region can be understood as a region that is sparse with many conflicts. The conflict in the Middle East region is increasing so it needs constructive and sustainable ways to minimize the development of conflict. Among those in the spotlight of the international community is the mounting conflict after the Saudi Arabia's death sentence was imposed on the Iranian cleric Sheikh Nimr Al-Nimr. Seeing the heating conditions in the Middle East region, Indonesia offered to participate in reconciling the conflicts between the two countries. This problem is further analyzed using the theory of conflict, mediation and national interests. In this study using the method of Library Studies (Library Research) with descriptive data presentation. Literature study is meant in this research is to collect data from the field such as books, journals, research reports, websites and others that have information relevant to the research topic. Based on the results of the discussion it can be concluded 
P-ISSN $2580-7781$

E-ISSN 2615 - 3238

that the involvement of Indonesia which has good relations with the two countries is to assist efforts to resolve the conflict peacefully so as not to have a major influence on neighboring countries. The reason Indonesia is involved as a mediator of the conflict between Saudi Arabia and Iran is because it has domestic support supported by the Indonesian Ulema Council (MUI) and there are several national interests such as economic interests and social interests of the two countries.

Keywords: Conflict, Saudi Arabia, Iran, Indonesia, Mediator

\section{PENDAHULUAN}

Kawasan Timur Tengah memang selalu menjadi perhatian negara-negara tetangga, termasuk Indonesia. Banyaknya pergolakan yang menjadi-jadi membuat bangsa Indonesia prihatin atas hal tersebut. Faktor yang mempengaruhi tingginya perhatian Indonesia terhadap wilayah Timur Tengah salah satunya karena adanya kedekatan emosional berupa keagamaan diantara Indonesia dengan negara-negara diwilayah Timur Tengah (Annisa Karimah 2017 : 2).

Pada awal tahun 2016, dunia dikejutkan dengan konflik yang kembali terjadi antara Arab Saudi dengan Iran. Ditambah lagi memang sejak dahulu kedua negara tersebut adalah negara-negara Timur Tengah yang mempunyai hubungan tidak baik. Konflik ini berawal pada tahun 2016 tanggal 2 Januari, dimana pemerintah Riyadh telah mengumumkan bahwa mengeksekusi 47 orang dan salah satu dari mereka adalah Ulama Besar Syi'ah Nimr al Nirm (Rita Uli Hutapea 2016). Setelah beberapa jam pengumuman disampaikan rakyat Iran melakukan aksi protes, berusaha masuk ke gedung kedutaan, merusakkan serta membakar kedutaan Arab Saudi yang berada di Teheran. Akibat dari insiden aksi protes tersebut, pada 3 Januari 2016 pemerintah Arab Saudi meminta kedutaan Iran pergi meninggalkan Arab Saudi serta diputuskanlah memutuskan hubungan diplomatic dengan Iran saat itu juga.

Pada tahun 2014, Al-Nimr dijatuhi vonis hukuman mati oleh pengadilan Arab Saudi dengan didakwa lantaran membangkang terhadap perintah negara dan diduga merencanakan penbunuhan terhadap aparat keamanan. Mulai saat itu, AlNimr yang berusia 54 tahun menjadi sanderaan politik antara Teheran dan Riyadh (Egidius Patnistik, 2016).

Memanasnya hubungan kedua negara ini tidak hanya mengakibatkan pemutusan hubungan diplomasi antara Arab Saudi dengan Iran, akan tetapi 
P-ISSN $2580-7781$

E-ISSN 2615 - 3238

Negara-negara teluk sekutu Arab Saudi ikut serta berbondong-bondong memutuskan hubungan doplomasi dengan Iran, diantaranya adalah Bahrein, Sudan, Yordania, Kuwait, Qatar, Djibouti dan Somalia (Aditya Mardiartuti, 2016). Sedangkan Uni Emirat Arab memilih untuk menurunkan status hubungannya dengan Iran. Banyaknya negara-negara yang ikut serta memilih untuk memutuskan hubungan diplomatik karena beranggapan bahwa Iran telah melanggar kesepakatan Internasional dengan tidak menjaga keamanan diplomat.

Banyaknya Negara yang ikut andil dalam menghentikan hubungan diplomatik dengan Iran membuat Indonesia yang sebagian besar adalah Negara dengan penduduk Islam terbesar juga diajak dalam satu aliansi untuk memutuskan hubungan diplomatik, akan tetapi Presiden Jokowi dengan tegas menolak ajakan tersebut yang datang dari Arab Saudi untuk mendukung konfliknya dengan Iran (Ferry Kisihandy, 2016). Sehingga jalan yang ditempuh Indonesia dalam menyikapi perseteruan antara Arab Saudi dengan Iran adalah diposisi netral.

Dengan adanya konflik yang sedang memanas, Indonesia sebagai negara yang memiliki hubungan kerjasama yang baik terhadap Arab Saudi dan juga Iran mengajukan tawaran untuk ikut serta dalam menyelesaikan konflik yang terjadi terhadap keduanya. Keterlibatan Indonesia dalam konflik tersebut dibantu oleh OKI (Organisasi Kerja Sama Islam), peran yang dilakukan Indonesia dalam menyelesaikan konflik ini memiliki tujuan untuk memajukan kerjasama internasional dengan negara-negara Islam, untuk menumbuhkan rasa solidaritas Keislaman diantara negara-negara anggota OKI, mendukung perdamaian sera keamanan internasional dan menjaga tempat-tempat suci peribadahan Islam. Penyelesaian konflik Arab Saudi dengan Iran memerlukan kerjasama yang baik dengan negara-negara Islam melalui OKI (Organisasi Kerja Sama Islam).

Keseriusan Indonesia untuk menengahi konflik Arab Saudi dengan Iran ditunjukkan oleh pemerintah Indonesia dengan mengirimkan Menteri Luar Negeri Indonesia Retno Marsudi untuk berkunjung kedua negara tersebut. Pada tanggal 13 Januari 2016, Menlu Retno bertemu dengan Menlu Iran yaitu Muhammad Javad Zarif dan Presiden Hassan Rouhani untuk menyerahkan surat dari Presiden Joko Widodo yang berisi tentang keprihatinan Indonesia terhadap hubungan 
P-ISSN $2580-7781$

E-ISSN 2615 - 3238

antara Arab Saudi dengan Iran (Kemenlu RI, 2016). Didalam isi surat tersebut disampaikan bahwa Indonesia siap membantu memperbaiki hubungan Arab Saudi dengan Iran. Pada tanggal 18 Januari 2016, Menlu Retno juga menyampaikan pesan perdamaian dari Presiden Joko Widodo kepada Raja Saman di Istana AlYammah, Riyadh. Dalam surat tersebut menekankan pada pentingnya stabilitas dan perdamaian kawasan, dan pentingnya hubungan baik terhadap kedua negara tersebut.

Konflik yang terjadi diantara Arab Saudi dengan Iran yang mengakibatkan Indonesia menawarkan diri untuk andil terjun mendamaikan konflik akan dikaji melaui konsep mediasi yang mana dalam melakukan perannya Indonesia hanya mempunyai wewenangan sebatas memberikan saran. Menurut Syahrizal Abbas (2009 : 25) Mediator tidak sepenuhnya memiliki kewenangan serta peran dalam menentukan isi persengketaan, mediator hanya bertugas untuk menjaga proses yang dilaukan dalam mediasi berjalan serta dapat menghasilkan kesepakatan dari pihak-pihak yang sedang melakukan mediasi.

Selain itu konflik ini dikaji juga dengan teori kepentingan nasional yang tujuannya untuk mempertahankan dan menambah kekuasaan ke negara lain. Kepentingan nasional sendiri meliputi berbagai aspek yaitu ekonomi, keamanan, diplomasi serta aspek lain yang tujuannya melindungi aset-aset diplomatik negara. Menurut Morgenthau dalam Rama Marito Sinaga (2018 : 1095-1096) dijelaskan bahwa kepentingan nasional didasarkan bahwa strategi diplomasi harus didasarkan terhadap kepentingan nasional. Kepentingan nasional tiap-tiap negara yaitu untuk mengejar kekuasaan, yang artinya segala sesuatu yang dapat membentuk serta mempertahankan kendali suatu negara terhadap negara lain. Morgenthau menyatakan bahwa perilaku negara dalam hubungan internasional dituntun oleh pengejaran kepentingan nasional, dan kepentingan nasional itu adalah memperoleh, mempertahankan serta memperbesar kekuatan negara.

Berdasarkan latar belakang yang sudah diuraikan diatas, jadi rumusan masalah yang dapat diambil dalam penelitian ini adalah Bagaimana analisis kebijakan Indonesia sebagai mediator konflik antara Arab Saudi dan Iran pada tahun 2016 ? 
P-ISSN 2580 - 7781

E-ISSN 2615 - 3238

\section{METODE PENELITIAN}

Penelitian ini bersifat deskriptif dengan menggunakan jenis penelitian studi Pustaka (Library Research). Dalam penelitian Studi Pustaka ini yang dimaksud adalah dengan mengumpulkan data dari lapangan atas bacaan-bacaan literatur yang memiliki informasi dan relevan dengan topik penelitian. Metode pengumpulan data yang digunakan yaitu dengan menelaah berbagai literatur yang berkaitan terhadap topik penelitian seperti buku, jurnal, laporan hasil penelitian, website dan lain sebagainya yang sesuai dengan permasalahan yang ingin dipecahkan dalam penelitian ini (Zed Mestika 2014 : 3).

\section{HASIL PENELITIAN DAN PEMBAHASAN}

\section{Konflik Arab Saudi dan Iran}

Revolusi Iran tahun 1979 merupakan awal memburuknya hubungan antara Arab Saudi dengan Iran. Pada waktu itu, Pemerintah Arab Saudi menyetujui pemerintahan baru serta Raja Khalid memberikan surat kepada Ayaatollah Khomeini yang bertuliskan ucapan selamat atas keberhasilan terhadap republik baru dan mengungkapkan kesediaan bahwa Arab Saudi siap melaksanakan kerjasama baik dengan mereka serta mendirikan kerjasama yang berorientasi pada "solidaritas Islam" yang didasarkan atas hubungan kedekatan Arab Saudi dengan Iran (Emil dan Gustri, 2018 : 252). Pada pertengahan tahun 1979, Isu-isu Syiah diwilayah Timur Tengah mendapatkan dukungan dari Iran dan juga Khomeini menerangkan bahwa Iran berperan menjadi pengekspor revolusi. Namun demikian setelah Iran melakukan Transformasi menjadi negara Syiah, hal tersebut membuat Arab Saudi (Sunni) lebih meningkatkan pengaruh terhadap Wahabi diwilayah Timur Tengah.

Revolusi Iran menciptakan pertempuran sekterian yang besar antara Sunni dan Syi'ah. Kedua negara tersebut berusaha memberikan pengaruh terhadap penduduk diwilayah Timur Tengah dengan melalui penyaluran kebudayaan serta politik menurut mereka, yang paling utama melalui inti religiunitas penduduk diwilayah Timur Tengah (Emil dan Gustri, 2018 : 253). Dengan strategi pengukuhan Islam, Arab Saudi mencoba untuk membatalkan usaha Khomeini dan membatasi perjuangan Syi'ah. Arab Saudi memiliki banyak kekayaan sumber 
P-ISSN $2580-7781$

E-ISSN 2615 - 3238

minyak, sehingga Arab Saudi memiliki kemampuan tidak hanya dapat menolak tantangan Khomeini, akan tetapi juga mampu memberikan pengaruh muslim dunia untuk merenggut pengaruh Iran. Sekterianisme mulai didorong oleh Arab Saudi sehingga mengakibatkan golongan Sunni memberontak terhadap Syi'ah serta pemerintah Sunni didukung untuk menaklukkan aktivisme keislaman dan upaya untuk reformasi politik.

Tahun 1980 sampai 1988 hubungan antara Arab Saudi dengan Iran menegangkan Kembali akibat perang antara Iran dengan Irak. Memuncaknya perang antara Iran dengan Irak tersebut atas dasar peran dari Ideologi Iran serta geopolitik kawasan Irak. Munculnya isu tersebut diantaranya adanya persaingan kebudayaan yang lama antara Arab Saudi dengan Persia. Walaupun Arab Saudi mempunyai permasalahan sendiri dengan Irak, Arab Saudi tetap mendukung rezim Saddam Hussein di Baghdad. Riyadh juga mengirimkan bantuan dana 25 milyar US Dollar dan memberikan desakan terhadap negara-negara teluk guna menyumbangkan dana untuk perang di Irak.

Pada tahun 1987, hubungan Arab Saudi dengan Iran tegang kembali karena jemaah haji Iran setiap tahun selalu berdemonstrasi di Mekkah dan Madinah untuk menentang Israel (Hanna Azarya Samosir, 2016). Akan tetapi pada 1987, polisi anti huru hara Arab Saudi memblokade jalan menuju Masjidil Haram. Akibatnya, terjadi bentrokan antara polisi anti huru hara Arab Saudi dan demonstran Iran. Sekitar 402 orang tewas (sebagian besar umat Syiah Iran) dan 649 luka-luka. Tak hanya itu, bentrokan tersebut juga membuat massa Iran semarin marah dan membalasnya dengan cara menduduki kedutaan Arab Saudi dan Kuwait. Seorang diplomat Arab Saudi tewas karena terjatuh dari jendela kedutaan. Pemimpin Iran Tertinggi yaitu Ayatollah Ruhollah Khomeini menyatakan bahwa monarki Saudi adalah bidah. Sehingga selama empat tahun hubungan diplomatik antara negara Arab Saudi dengan Iran terputus.

Pada April 2001, hubungan antara Arab Saudi dengan Iran membaik pasca pemilihan umum presiden Iran yaitu Mohammad Khatami terpilih dan melakukan kunjungan resmi pertama Presiden Iran pada tahun 1979 ke Arab Saudi. Setelah itu, kedua negara tersebut menandatangani perjanjian keamanan. Raja Fahd 
P-ISSN $2580-7781$

E-ISSN 2615 - 3238

memberikan selamat kepada Mohammad Khatami terpilih menjadi presiden Iran pada 2001. Fahd menilai Khatami akan memberikan kebijakan reformis. Khatami berupaya untuk memulihkan hubungan dengan Riyadh bahkan sebelum menang pada pemilihan 1997 Khatami pun mengunjungi Saudi (Hanna Azarya Samosir, 2016).

Hubungan antara Iran dengan Arab Saudi kembali terpuruk, tepatnya pada tahun 2003 ketika invasi Amerika Serikat di Irak berhasil menggulingkan Saddam Hussein (Hanna Azarya Samosir, 2016). Selama 82 tahun, Irak saat itu didominasi oleh Sunni dan Syiah sebagai minoritas yang tertekan dan terpinggirkan. Penindasan terhadap kaum Syi'ah terlihat sangat jelas di bawah kekuasaan Saddam Hussein dan partai Ba'ath. Pada saat Rezim Saddam Hussein, masyarakat Syi'ah terjadi diskriminasi dan juga dibatasinya kebutuhan manusia yang mendasar, termasuk kesejahteraan psikologis.

Pada 2004, kelompok Syiah Zaidiyah di Yaman melakukan pemberontakan. Arab Saudi menuding Iran telah menghasut dan ikut campur mengurus perkara dalam negeri Yaman dengan cara memasok senjata ke Yaman. Sedangkan Iran menuding Arab Saudi telah mengkhianati perannya sebagai mediator konflik dengan membombardir minoritas Hauthi di utara Yaman. Pada 2006, terjadi Perang Israel dan Milisi Libanon, Hizbullah. Dukungan Iran terhadap Hizbullah di tunjukkan dengan menyuplai senjata ke Hizbullah. Arab Saudi menaruh curiga Iran mencoba membangun aliansi baru untuk mengancam kepentingan Saudi. Pada 2011, gerakan pro-demokrasi dan antirezim telah menjatuhkan rezim di negara - negara Arab, mulai dari Mesir, Tunisia, Libya, dan Yaman, serta telah memicu protes massa dan pemberontakan di banyak negara di seluruh Arab mulai dari Maroko, Aljazair ke wilayah Palestina, Yordania, Lebanon, Suriah, Bahrain, Qatar, Kuwait, Uni Emirat Arab, dan Arab Saudi (Zuhairi Misrawi, 2018) .

Pada 14 Februari 2011, gerakan oposisi di Bahrain mulai menyerukan reformasi konstitusi, pemilu, dan pembebasan tahanan dari khalifa kerajaan. Gerakan ini berhasil melibatkan sebagian besar populasi Syi'ah disana. Pemberontakan Bahrain membuat Arab Saudi takut akan bertambahnya populasi Syi'ah yang memberontak. Kericuhan di Bahrain telah membuat Arab Saudi takut 
P-ISSN $2580-7781$

E-ISSN 2615 - 3238

sekutunya akan jatuh dan beralih ke Iran. Arab Saudi mengirim 1000 tentara untuk membantu pemerintah Bahrain untuk menghadang para demonstran yang mayoritas adalah Syiah yang syarat akan kepentingan Iran dan menekan tindakan brutal yang dilakukan oleh demonstran. Pada ditahun yang sama, Arab Saudi juga mengambil sikap terhadap program nuklir Iran. Program nuklir Iran sendiri dimulai pada tahun 1970 di era Shah Reza Pahlevi. Isu nuklir menjadi menonjol di era Ahmadinejad. Awalnya tujuan program nuklir Iran adalah untuk membangun sektor nuklir. Ketakutan Arab Saudi terlihat dari kecurigaan Arab Saudi akan program energi nuklir Iran pada era Presiden Mahmoud Ahmadinejad. Arab Saudi yakin bahwa Iran bertekat untuk mendominasi kawasan Teluk dan meningkatkan pengaruh politik serta penyebaran syiah di kawasan. Keresahan Arab Saudi diperparah menyusul adanya laporan dari intelejen yang mengungkapkan ambisi nuklir Iran. Akan tetapi, Iran menegaskan bahwa program nuklir yang mereka rancang hanya untuk tujuan damai.

Sebagai saingan utama dalam ideologi Iran, Arab Saudi telah mengumumkan rencana untuk membangun program nuklirnya sendiri dengan minimal 16 sektor nuklir. Arab Saudi memiliki sejarah bertindak secara sembunyi-sembunyi di arena nuklir, memungkinkan produksi bom Sunni untuk melawan bom Syi'ah. Arab Saudi menganggap bahwa nuklir Iran mengancam stabilitas dunia dan membawa proliferasi nuklir ke Timur Tengah. Pada Tahun 2015, lebih dari 400 jemaah haji Iran meninggal di terowongan Mina akibat panic massa. Iran menuding pemerintah Arab Saudi ikut bertanggungjawab dalam tragedy ini.Sebaliknya, Arab Saudi menyelipkan isu bahwa tragedy itu disebabkan oleh jemaah haji Iran yang tidak mau diatur. Kisruhpun memuncak saat pangeran Arab Saudi, Khalid bin Abdullah, mendesak agar Riyadh melarang masuk jemaah haji Iran.

Pada tahun 2016, pemerintah Arab Saudi mengeksekusi seorang ulama Syiah yaitu Syaikh Nimr Baqr Al-Nimr yang merupakan salah satu kiritikus kelompok Syiah yang memperjuangkan kesetaraan Syiah dinegara Arab Saudi. Eksekusi mati Nimr dilaksanakan tanggal 2 Januari 2016 bersamaan dengan 47 tahanan lainnya diantaranya 3 warga Syiah dan 44 lainnya merupakan tahanan 
P-ISSN $2580-7781$

E-ISSN 2615 - 3238

yang mengancam keamanan nasional negara Arab Saudi (Rita Uli Hutapea, 2017).

Dampak dari tindakan Arab Saudi ini menuai respon dari rakyat Iran untuk melakukan protes di depan Kedutaan Arab Saudi tepatnya Teheran. Massa mencoba masuk ke dalam gedung, menghancurkan dan memantik api, sebelum akhirnya dibubarkan oleh polisi Pasca unjuk rasa tersebut, diputuskannya hubungan diplomatik dengan Iran oleh Arab Saudi dan meminta diplomat Iran pergi dari Arab Saudi dalam hitungan waktu 2 kali 24 jam. Menurut Hossein Jaberi Ansari selaku juru bicara Kementerian Luar Negeri Iran bahwa Arab Saudi hanya memanfaatkan insiden (penyerangan kedutaan) sebagai alasan guna meninggikan ketegangan (Rita Uli Hutapea, 2017).

Pasca eksekusi hukuman mati terhadap Nimr Al-Nimr asal Iran bersamaan dengan 46 terpidana lainnya dengan tuduhan terlibat aksi terorisme, konflik kian menyebar di kawasan Teluk dan Timur Tengah. Jika hal tersebut dibiarkan maka memberikan dampak negatif yang ditimbulkan meluas dan mengglobal baik menyangkut gesekan religius-sektarian, ekonomi khususnya minyak, militer dan rebutan dominasi pengaruh kawasan Teluk. Bukan rahasia lagi bahwa Arab Saudi adalah negara produsen minyak terbesar dunia dan Iran dikenal dengan kemampuan senjata nuklir.

Rivalitas antar kedua negara berpotensi memicu kawasan Teluk menjadi lautan api. Bila eskalasi konflik menjadi perang, maka negara-negara pro Arab Saudi tidak akan tinggal diam, begitu pula dengan Iran. Arab Saudi dengan segala kekuatan eknomi minyak dan senjata modern dari sekutu Amerika dan dukungan sekutu negara-negara teluk akan menjadi kekuatan luar biasa. Demikian pula Iran, sekutunya Rusia, China serta Suriah, Irak dan Yaman tentu tidak akan tinggal diam. Apalagi Iran berpotensi memiliki senjata nuklir, mampu memproduksi berbagai peralatan militer modern yang membuat timpang hegemoni militer di kawasan Teluk.

Konflik tersebut juga diprediksi memicu harga minyak dunia naik karena terganggunya jalur suplai dan produksi dunia. Kemungkinan lainnya malah sebaliknya, harga minyak dunia anjlok karena pihak yang bertikai memproduksi minyak secara besar-besaran untuk biaya perang (Anto Kurniawan, 2016). 
P-ISSN $2580-7781$

E-ISSN 2615 - 3238

Apalagi di Arab Saudi terdapat dua kota suci Islam yakni Mekkah dan Madinah, di Teluk Bab El-Mandeb menjadi jalur suplai 40\% ekspor minyak produksi Teluk ke AS dan Eropa, Laut Merah dan Terusan Suez menjadi jalur ekspor-impor internasional, negara-negara kawasan Teluk sebagai pusat bisnis dan keuangan dunia (Dubai, Doha dan Abu Dhabi), serta kekuatan militer Arab Saudi maupun Iran yang kuat, maka dampak negatifnya akan merata secara global.

Dengan adanya konflik ini Indonesia memiliki hubungan yang baik terhadap kedua negara tersebut. Hubungan Diplomatik Indonesia dengan Arab Saudi dengan resmi tercatat pada 21 November 1947 atau dapat disebut tepat pada 8 Muharram 1867 Hijriah, karena pada tanggal itu Kerajaan Arab Saudi menyetujui kemerdekaan serta kedaulatan RI. Pada tahun 1955, kantor kedutaan besar Arab Saudi dibuka di Indonesia tepatnya di Jakarta. Sedangkan tahun 1964 barulah kantor kedutaan Indonesia dibuka di Arab Saudi yang letaknya di Jeddah. Tanggal 29 September 1985 kedutaan besar Republik Indonesia selanjutnya dipindahkan dari Jeddah ke Riyah. Perwakilan Indonesia statusnya diganti di Jeddah menjadi Konsulat Jenderal Indonesia .

Hubungan antara Indonesia dengan Arab Saudi dikuatkan dengan adanya hubungan kerjasama di bidang keagamaan, kebudayaan, serta politik. Tentunya ini dimudahkan sama-sama memberi pengertian terhadap adanya isu-isu hubungan bilateral dan juga internasional sehingga adanya ketertarikan itu menguatkan keinginan dua negara tersebut dalam melaksanakan kerjasama dalam bidang ekonomi, pariwisata, investasi, energi, transportasi, serta ketenagakerjaan. Sedangkan hubungan diplomatik antara Indonesia dengan Iran dimulai pada tahun 1950 dalam tingkat kedutaan. Mayjen R.H. Abdul Kadir dengan gelar Duta Besar kepala perwakilan RI dan merangkap Menteri berkuasa penuh RI. Tahun 1960 tingkat kedutaan RI ditinggikan menjadi Kedutaan Besar RI. Sebagai duta besar LBBP RI untuk yang pertama, Pemerintah RI memilih M.Bachmid.

Indonesia mempunyai kedutaan tepatnya diwilayah Teheran dan juga Iran mempunyai kedutaan besar tepatnya di Jakarta. Ditingkat global negara Indonesia dengan Iran merupakan anggota penuh gerakan Non-Blok (GNB) dan kelompok D-8. Kerjasama yang dilakukan antar kedua negara tersebut meliputi 3 bidang 
P-ISSN $2580-7781$

E-ISSN 2615 - 3238

antara lain bidang politik, kebudayaan, dan ekonomi. Dalam Hubungan politik kedua negara berjalan dengan baik yang antara lain ditandai dengan saling kunjung Kepala Negara/Pemerintah. Tahun 2006 Presiden Mahmoud Ahmadinejad mengunjungi Indonesia sedangkan Presiden Susilo Bambang Yudhoyono melakukan kunjungan balasan ke Iran pada tahun 2008. Kedua negara saling memberikan dukungan dalam pecalonan pada jabatan atau keanggotaan organisasi internasional.

Indonesia dengan Iran tetap berusaha untuk menggunakan berbagai kesempatan guna meningkatkan terciptanya hubungan perdagangan negara. Iran adalah sahabat serta mitra yang strategis untuk Indonesia. Hubungan bilateral antara Indonesia dengan Iran sangat erat pasca pertemuan bilateral antara Indonesia dan Iran pada bulan Maret 2016 di KTT KAA dan KTT luar biasa OKI (Rama Marito Sinaga, 2018: 1097-1098). Momen tersebut terlindungi pasca penerapan JCPOA yang mengambil sebagian sanksi ekonomi terhadap negara Iran. Sebagai mitra baik kerjasama Indonesia dengan kedua negara tersebut hal ini sebagai dasar Indonesia terlibat dalam menengahi konflik.

\section{Kebijakan Politik Luar Negeri Indonesia sebagai Mediator Konflik Antara Arab Saudi Dengan Iran}

Menurut Laode Muhammad Fathun (2018: 325-326) Pada konteks perumusan kebijakan luar negeri Indonesia yang disesuaikan dengan nilai-nilai dasar nasional yang diambil dari konstitusi Indonesia yaitu Undang-Undang Republik Indonesia Pasal 1 No 37 Tahun 1999 Tentang Hubungan Luar Negeri yang merupakan suatu kebijakan, sikap, serta cara Pemerintah Indonesia guna menjalankan hubungan terhadap negara lain, organisasi internasional, serta subyek hukum internasional lainnya untuk menghadapi permasalahan internasional dalam rangka mencapai tujuan nasional. Selanjutnya pada Pasal 3 yaitu tentang Politik Luar Negeri yang berasas bebas aktif guna mencapai kepentingan nasional. Lebih lanjut pada Pasal 4, Politik Luar Negeri dilaksanakan melalui diplomasi yang sangat kreatif, aktif serta antisipatif, tidak hanya rutin maupun reatif, berpegang teguh prinsip serta berpendirian, dan rasional serta luwes. Indonesia sebagai negara merdeka serta berdaulat, dengan melaksanakan 
P-ISSN $2580-7781$

E-ISSN 2615 - 3238

hubungan luar negeri dan Politiknya berdasarkan asas persamaan derajat, saling hormat, saling untung, serta saling tidak campur dengan urusan dalam negeri masing-masing negara, seperti makna tersirat dalam Pancasila maupun UndangUndang Dasar 1945 Pasal 2.

Kebijakan luar negeri adalah salah satu tindakan atau gagasan yang disusun oleh para pembuat kebijakan guna menyelesaikan suatu permasalahan serta memberikan suatu tanggapan terhadap terjadinya perubahan dalam lingkungan internasional yang dilakukan dengan cara menyampaikan kebijakan, sikap bahkan tindakan yang didasarkan pada pertimbangan tertentu guna mencapai tujuantujuan yang dikehendaki (Gian Angga, 2017: 1203).

Indonesia ikut andil dalam menyelesaikan permasalahan dunia dengan cara damai. Penyelesaian konflik Timur Tengah salah satunya dalam perang antara Israel dengan Palestina mempengaruhi kepentingan Indonesia juga, diantara yaitu Indonesia dengan Timur Tengah adalah anggota gerakan Non-Blok, OKI serta OPEC. Sejarah mengatakan bahwa, negara-negara yang berada di Timur Tengah merupakan golongan pertama yang mengakui kemerdekaan Indonesia. Maka dari itu, pada tanggal 5 November 1956 PBB menyatakan bahwa akan membentuk pasukan guna menjaga keamanan serta mengawasi pemutusan tindakan perseteruan antar negara diwilayah Timur Tengah.

Sebagai mediator saat melaksanakan tugasnya hanya mempunyai wewenang untuk memberi saran serta mengatur proses berlangsungnya mediasi guna mengupayakan jalan damai pemecahan sengketa. Mediator tidak mempunyai kewenangan dan tidak dapat memutuskan bagaimana kaitannya dengan isi permasalahan, mediator hanya dapat memelihara jalannya mediasi, sehingga dapat membuahkan hasil kesepakatan dari pihak yang berseteru (Syahrizal Abbas, 2019). Kebijakan yang diambil oleh Indonesia sebagai mediator konflik ini sudah sesuai dengan Undang-Undang Nomor 37 Tahun 1999 sehingga dapat mewujudkan upaya komunikasi yang baik dengan wakil-wakil negara yang berseteru untuk merebut kepentingan nasional dengan jalan damai.

Eksekusi mati bagi ulama besar Syiah di Arab Saudi yaitu Sheikh Nimr alNimr membuat konflik antara Arab Saudi dengan Iran semakin terlihat 
P-ISSN $2580-7781$

E-ISSN 2615 - 3238

menegangkan. Seperti yang diberitakan, aksi masa menyerang kantor Kedutaan Arab Saudi di Teheran, Riyadh menyudahi hubungan diplomatik terhadap Teheran (Gian Angga, 2017 : 1203). Ketegangan hubungan antara negara tersebut saling berpengaruh diwilayah ini dan menjadi bentuk konflik yang utama diwilayah Timur Tengah. Sehingga menimbulkan keresahan masyarakat internasional dari ketegangan hubungan antara Arab Saudi dengan Iran terhadap kestabilan wilayah, mengingat banyaknya konflik yang terjadi antara kedua negara tersebut mengakibatkan perang tidak langsung (proxy war) di negaranegara wilayah Timur Tengah. Masyarakat-masyarakat internasional salah satunya Indonesia, sudah selayaknya membantu terciptanya perdamaian diwilayah Timur Tengah tersebut (Laode Muhammad Fathun, 2018 : 331).

\section{Kepentingan Nasional Indonesia Sebagai Mediator Konflik Antara Arab Saudi Dengan Iran}

\section{a. Kepentingan Ekonomi Perdagangan Indonesia}

Ekspor merupakan kegiatan mendagangkan barang ke luar negeri. Indonesia mengekspor hasil kekayaan alamnya. Berdasarkan sumber daya alamnya sehingga dapat memproduksi banyak barang yang dieksporkan. Indonesia mengekspor barang yang disukai dan diperlukan oleh negara lain. Salah satu tujuan ekspor Indonesia adalah negara Timur Tengah dengan berkembangnya kawasan Timur Tengah seperti Uni Emirat Arab, Qatar dan Oman, maka kerjasama perdagangan Indonesia beserta Timur Tengah akan semakin meningkat. Komoditas yang diperdagangakan Indonesia antara lain adalah kelapa sawit, kertas, dan termasuk indomie yang memiliki pabrik di Dubai. Salah satu ekspor Indonesia diwilayah Timur Tengah yaitu Arab Saudi dan juga Iran (Fadhylatur Rizqah Isdah, 2018 : 59). Membaiknya hubungan Indonesia dengan Arab Saudi telah melakukan kerjasama bilateral dalam bidang ekonomi. Komoditi utama Indonesia mengekspor kenegara Arab Saudi seperti Plywood, venner, pakaian jadi, tekstil, kertas dan produk kertas, ban, furniture, electric appliances, electrical machineries. Selain itu Impor barang yang dilakukan Indonesia dari negara Arab Saudi yaitu Aliminuim, serat sintetik, alcohols, phenols, phenol alcohol, hidro- 
P-ISSN $2580-7781$

E-ISSN 2615 - 3238

carbon, ethylene, pulp dan sisa kertas, logam, kimia organik, dan juga migas (Fadhylatur Rizqah Isdah, $2018:$ 74).

Pada tanggal 2 Maret 2017 dalam rangka datangnya Raja Salman ke Indonesia yaitu guna diadakannya beberapa penandatanganan MoU serta dokumen kerja sama antara dua negara tersebut, salah satunya dalam bidang perdagangan (Danu Damarjati, 2017). Penandatanganan disaksikan langsung Presiden Jokowi beserta Raja Salman yang digelar dalam Istana Bogor. Indonesia dengan Arab Saudi menyepakati akan mengembangkan kebijakan perdagangan luar negeri dengan menjalankan riset pemasaran serta saling memberikan informasi mengenai perdagangan. Dan juga, dua negara tersebut menyetujui untuk saling memberi pengalaman dalam bidang basis data perdagangan serta mensuport keikutsertaan dunia usaha dalam berbagai forum, kegiatan workshop, serta digelarnya seminar (Andreas Lukas, 2017).

Kesepakatan program hubungan Kerjasama dari Economic and Technical Cooperation Agreement between Republic of Indonesia and the Kingdom of Saudi Arabia sudah resmi ditandatangani mulai tahun 1981 oleh dua negara tersebut. Dengan terjalinnya kerjasama ini adanya peningkatan ekspor Indonesia dalam bidang non migas ke Arab Saudi terlihat dalam nilai perdagangan Indonesia dengan Arab Saudi pada tahun 2016 sebesar USD 4,06 miliar atau dapat dikatakan turun dengan prosentase 25,98\% dibandingkan dengan tahun 2015. Pada tahun 2016 tujuan ekspor terbesar yang dituju oleh Indonesia diwilayah Timur Tengah adalah Arab Saudi dengan jumlah nilai sebesar USD 1,33 miliar, sedangkan Arab Saudi melakukan impor ke Indonesia senilai USD 2,73 miliar. Dikarenakan Indonesia mengimpor migas dari Arab Saudi sangat besar ditahun 2016 terjadilah defisit neraca perdagangan Indonesia sebesar USD 1,39 milliar. Sebaliknya untuk ekspor neraca perdagangan nonmigas, Indonesia mendapat surplus sebesar USD 627,5 juta (W, Ganewati 2016).

Sedangkan Iran, Indonesia telah melakukan kejasama dengan Iran dalam bidang ekonomi. Komoditi utama ekspor Indonesia ke Iran adalah minyak sawit, pelat/sheets, kertas\&karton, rokok, serat tiruan, karet alam, minyak/lemak nabati, ban vulkanisir, sepeda motor, piston mesin, teh hitam. Sedangkan import 
P-ISSN $2580-7781$

E-ISSN 2615 - 3238

Indonesia dari Iran berupa bahan kimia anorganik, senyawa logam mulia, bahan bakar mineral, mesin, reactor, boiler, bahan kimia organic, besi dan baja, plastic minuman, akohol dan cuka. Dalam kunjungan Jokowi ke Iran, akhir Desember 2016, membahas kerjasama ekonomi kedua negara. Ada dua pokok bahasan yang dibicarakan. Pertama, kerjasama di sektor migas. Ayatollah Khamenei menyebutkan potensi kerjasama ekonomi RI-Iran bisa mencapai 20 miliar dollar AS, sehingga Iran telah memperkenankan pertamina untuk berinvestasi di ladang minyak Mansouri serta Ab-Teymour (Utami Nadirah Ramadhani, 2018 : 62). Kedua, Selain kerjasama dalam bidang energi Iran terkesan dengan kerjasama bidang infrastruktur dengan meningkatkan kegiatan ekspor maupun impor untuk dua pihak (Rama Marito Sinaga, 2018: 1096).

Kunjungan Jokowi ke Iran sebagai langkah untuk meningkatkan produksi ekspor RI ke Iran, dimana salah satunya adalah melakukan "Direct-trade" dengan adanya direct-trade memungkinkan produk RI akan lebih bersaing karena selama ini transaksi perdagangan melalui pihak ke tiga. Iran juga berharap agar adanya penerbangan berjadwal dari Teheran ke Jakarta. Penerbangan berjadwal diharapkan bisa meningkatkan sektor pariwisata dan perdagangan kedua negara (Reinhard F Hutabarat, 2017). Neraca perdagangan Indonesia-Iran mengalami tren penurunan sejak 2011 lalu. Pada 2015, jumlah total perdagangan bilateral dua negara sebesar US\$273,1 juta atau turun 38,51 persen dari 2011 yang mencapai US\$ 1,8 miliar. Adapun per Agustus 2016 nilai perdagangan bilateral hanya berkisar US\$ 150 juta, lebih rendah dari capaian periode sama tahun lalu sebesar US\$195 juta.

Berdasarkan pemaparan diatas tersebut Indonesia melakukan kerjasama dengan negara Arab Saudi dan juga Iran dalam ekspor dan impor tercipta cukup baik. Apabila ketegangan politik negara-negara diwilayah Timur Tengah meluas ke Arab maka akan berpengaruh terhadap hubungan perdagangan Indonesia dengan Arab maupun Iran karena Indonesia mengekspor barang ke Arab Saudi serta negara wilayah Timur Tengah lainnya melalui pelabuhan di Dubai. Sedangkan pengaruh lainnya, jika perperangan antara Iran dengan Arab terjadi maka kegiatan dagang negara-negara wilayah Timur Tengah akan sangat 
P-ISSN $2580-7781$

E-ISSN 2615 - 3238

terganggu. Arab dan Iran mempunyai garis pantai yang sangat panjang dikawasan Timur Tengah sehingga apabila ada zona perang tentunya kapal-kapal logistik yang melewati garis pantai tersebut harus lebih hati-hati bahkan dapat memperlambat waktu barang dikirim.

\section{b. Kepentingan Sosial perlindungan terhadap WNI di wilayah Timur Tengah}

Globalisasi telah meningkatkan lalu lintas barang, jasa, dan tenaga kerja melintasi batas-batas kenegaraan. Peluang penciptaan kerja di Indonesia sendiri belum cukup mampu mengatasi permasalahan banyaknya pengangguran serta pencarian kerja. Sehingga dipilihlah jalan alternatif agar tenaga kerja serta pencari pekerjaan memperoleh kerja yaitu memburu dengan pasar kerja di luar negeri. Mereka berharap bahwa dengan bekerja di luar negeri dapat menaikkan kesejahteraan hidupnya (Ferdinand Waskita, 2015). Yang menjadi pilihan utama buruh migran Indonesia yaitu wilayah Timur Tengah salah satunya Arab Saudi. WNI yang berada di luar negeri yaitu kawasan Timur Tengah merupakan Kawasan yang memiliki jumlah WNI terbesar setelah wilayah Asia Tenggara. Hal ini sangat menjadi sorotan khusus untuk pemerintah setelah kebijakan luar negeri Presiden Jokowi lebih memfokuskan perlindungan terhadap WNI di luar negeri (Abdul Fadhil, 2013 : 170).

Program penempatan TKI ke Arab Saudi sendiri secara resmi di mulai pada tahun 1975. Hal ini disebabkan adanya peristiwa "boom oil" pada tahun 1974 di negara Arab serta negara teluk lainnya, sehingga kebutuhan akan tenaga kerja yang berupah rendah meningkat tajam di negara tersebut. Pada awalnya tahun 1975 jumlah TKI sebanyak 25 orang dikirim ke Arab Saudi oleh pemerintah. Selanjutnya tahun 1976 jumlah dinaik hingga 480 orang, hingga tahun 1977 mengalami peningkatan 2.838 orang. Jumlah penempatan TKI tersebut semakin meningkat, terutama sejak krisis ekonomi Peristiwa "boom oil" dimana melonjaknya harga minyak di pasar internasional menyebabkan munculnya masyarakat kelas menengah di Arab Saudi sebagai negara pengekspor minyak dunia. Saat itulah muncul kebutuhan akan pembantu rumah tangga yang menjadi bagian dari gaya hidup masyarakat kelas tersebut (BNP2TKI, 2017). 
P-ISSN $2580-7781$

E-ISSN 2615 - 3238

Selain itu kerjasama dibidang ketenaga kerja hal ini dapat menguntungkan kedua pihak. Hal ini Arab Saudi dengan Iran juga mendapat keuntungan dikarenakan terbantunya oleh adanya tenaga kerja tambah untuk menaikan perekonomian mereka (Fadhylatur Rizqah Isdah, 2018 : 47). Sedangkan Indonesia mendapatkan devisa negara dari TKI yang telah bekerja di Arab Saudi maupun di Iran. Devisa TKI pada tahun 2014 mencapai USD 8,4 miliar, sedangkan pada tahun 2015 mencapai USD 10,5 miliar kemudian pada tahun 2016 devisa mengalami penigkatan sebesar 24 miliar. Selain pengiriman WNI ke Timur Tengah, Indonesia juga negara terbesar dalam aspek jumlah haji dan umrah. Menurut Saudi Press Agency pada tahun 2016 sebanyak 984,606 jamaah haji yang tiba di Arab Saudi. Mayoritas jemaah yang melakukan perjalanan dengan jalur udara berjumlah 930.608 sedangkan yang melakukan jalur laut ada 11.007 jemaah, dan yang melaukan perjalanan jalur darat sejumlah 42.991 jemaah. Otoritas Arab Saudi mengakui bahwa Indonesia adalah negara dengan penduduk muslim terbanyak di dunia. Dari 255 juta jiwa, terdapat 204 juta penduduk beragama Islam (BNP2TKI, 2016).

Berdasarkan pemaparan diatas menunjukan bahwa Indonesia tidak hanya mengirim TKI atau WNI kewilayah Timur Tengah salah satunya Arab Saudi serta Iran. Tetapi Indonesia juga merupakan negara yang melaksanakan haji serta umrah terbesar di dunia. Jika ketegangan antara Arab Saudi dengan Iran berlanjut hingga ke peperangan maka akan merugikan negara-negara regional disekitarnya atau negara-negara yang memilki kepentingan terhadap kedua negara tersebut. hal itupun akan berdampak pada Indonesia sendiri, apabila terjadi perang maka akan mengancam keselamatan WNI yang berada di Arab Saudi dan juga Iran sehingga membutuhkan usaha keras serta banyak biaya guna memastikan bahwa WNI yang berada diwilayah Timur Tengah baik-baik saja serta dapat pulang ke Tanah Air dengan selamat. Oleh karenanya Indonesia mengajukan diri untuk menjadi mediator di konflik tersebut.

Karena pada dasarnya penempatan serta penjagaan TKI di Luar Negeri sudah diatur dalam Undang-Undang Nomor 39 Tahun 2004 yang menyatakan bahwa penempatan TKI ke Luar Negeri adalah suatu program nasional yang 
P-ISSN $2580-7781$

E-ISSN 2615 - 3238

bertujuan untuk meningkatkan kesejahteraan tenaga kerja dan keluarganya dengan memanfaatkan pasar tenaga kerja internasional (UU No 39 Tahun 2004). Penempatan TKI di luar negeri juga merupakan usaha untuk menciptakan hak serta kesempatan yang adil untuk tenaga kerja guna mendapat kerja serta upah yang sepadan, yang pelaksanaannya dilakukan dengan cara tetap menjaga harkat martabat, hak asasi manusia dan juga pertahanan hukum serta penyediaan tenaga kerja yang dibagi merata kesempatan kerjanya sesuai dengan kebutuhan nasional. Penempatan TKI ke Luar Negeri dilaksanakan oleh instansi pemerintahan baik pusat maupun daerah dan juga peran aktif masyarakat untuk menjaga TKI yang berada di Luar Negeri.

\section{c. Adanya tuntutan dari Organisasi Internasional dalam negeri memberikan dukungan untuk memediasi konflik Arab Saudi dengan Iran.}

Arab Saudi dan Iran adalah dua negara yang saling berpengaruh. Arab Saudi disebut menjadi pusat kegiatan keislaman. Tiap tahun sudah menjadi rutinitas berjuta umat Islam melaksanakan tujuannya mengunjungi dua masjid suci, yaitu Masjidil Haram serta Masjid Nabawi di Madinah guna menjalanan umrah dan Haji. Sedangkan Iran merupakan negara dari kerajaan kuno Persia yang menjadi bagian dari sejarah perkembangan peradaban manusia. Banyak intelektual muslim lahir dari sini sejak zaman awal Islam.

Konflik antara Arab Saudi dengan Iran berawal ketika pemerintah Arab saudi mengeksekusi mati seorang ulama Syiah yaitu Nimr Baqr al-Nimr. Eksekusi tersebut memancing kemarahan rakyat Iran, sehingga sehari setelah eksekusi terjadi penyerangan terhadap kedutaan besar Arab Saudi di Teheran. Akhirnya, Arab Saudi memutuskan hubungan baiknya dengan Iran. Dengan adanya ketegangan terhadap kedua negara tersebut. Indonesia sebagai negara yang memiliki hubungan baik dengan kedua negara tersebut telah menawarkan diri untuk membantu upaya penyelesaian secara damai (Egidius Patnistik, 2016).

Hubungan Indonesia dengan Iran yang telah terjalin sejak akhir era 70-an semakin erat di era 90-an dan berlanjut hingga sekarang. Dengan adanya hubungan tersebut menjadi peluang Indonesia untuk masuk ke Iran dalam rangka 
P-ISSN $2580-7781$

E-ISSN 2615 - 3238

melakukan perdamaian. Kepercayaan Iran terhadap Indonesia diperlihatkan dengan dukungannya di berbagai banyak forum termasuk untuk posisi ketua gerakan non-blok.

Selain dengan Iran, Indonesia juga memiliki hubungan baik dengan Arab Saudi. Indonesia juga memilki track record hubungan baik dan harmonis. Kerjasama antar Indonesia dengan Arab Saudi telah terjalin kuat, baik dalam politik, ekonomi maupun pendidikan. Dari segala segi posisi Indonesia memang sangat strategis untuk melakukan langkah mendamaikan. Langkah awal sudah di perlihatkan oleh Majelis Ulama Indonesia yang tanggap meminta pemerintah untuk mengambil peran dalam meredakan konflik (Inggried Dwi Wedhaswary, 2016). Dalam pertemuan Presiden Jokowi dengan Majelis Ulama Indoneia (MUI) telah menyiapkan beberapa langkah taktis. Salah satunya menggelar konferensi negara-negara sahabat. Sebuah bentuk usaha lain yang patut pula diberikan apresiasi terkait dengan mendekatkan kedua negara tersebut. Dalam konferensi tersebut Presiden Jokowi tidak hanya dihadiri oleh negara yang ikut dalam Organisasi Konferensi Islam (OKI) saja, tapi seluruh negara-negara lain yang masih peduli terhadap perdamaian diwilayah Timur Tengah akan diundang (Affabile Rifawan, 2016).

\section{KESIMPULAN}

Berdasarkan hasil penelitian yang telah diuraikan diatas maka dapat disimpulkan bahwa konflik Arab Saudi dengan Iran merupakan konflik yang terjadi adanya faktor agama dan politik yang membuat ketidakstabilitas keamanan di kawasan. Konflik tersebut telah berawal dari revolusi Iran hingga pengeksekusian seorang ulama Syiah yaitu Nimr Baqr al-Nimr. Pengeksekusian ulama Syiah yang dilakukan oleh Arab Saudi ini mendapat respon dari masyarakat Iran. Sehari setelah eksekusi al-Nimr terjadi penyerangan terhadap kedutaan besar Arab Saudi tepatnya di Teheran. Dengan adanya penyerangan tersebut, Arab Saudi memutuskan hubungan baiknnya dengan Iran. Keterlibatan Indonesia yang memiliki hubungan baik dengan Arab Saudi dan juga Iran yaitu untuk membantu upaya penyelesaian konflik dua negara tersebut secara damai agar tidak berpengaruh besar terhadap negara-negara tetangga. 
P-ISSN $2580-7781$

E-ISSN 2615 - 3238

Adapun alasan Indonesia memutuskan siap bersedia menawarkan diri sebagai mediator konflik antara Arab Saudi dengan Iran didasarkan pada dukungan organisasi dalam negeri yaitu Majelis Ulama Indonesia (MUI) dengan menggelar konferensi OKI untuk negara-negara sahabat guna mendekatkan kedua negara yang berseteru, serta perumusan kebijakan luar negeri Indonesia yang disesuaikan dengan nilai-nilai dasar nasional yang diambil dari konstitusi Indonesia yaitu Undang-Undang Republik Indonesia Nomor 37 Tahun 1999 Tentang Hubungan Luar Negeri Indonesia dengan menganut prinsip Politik Luar Negeri bebas aktif untuk diabdikan sebagai kepentingan nasional Indonesia yaitu Kepentingan ekonomi perdagangan Indonesia dan Kepentingan sosial terhadap perlindungan WNI dikawasan Timut Tengah.

\section{DAFTAR PUSTAKA}

Abbas, Syahrizal. 2009. Mediasi Dalam Perspektif Hukum Syariah, Hukum Adat dan Hukum Nasional. Jakarta: Kencana.

BNP2TKI. 2016. Remitensi TKI Mencapai Miliaran. https://bnp2tki.go.id diakses 28 Mei 2020.

BNP2TKI. 2017. TKI Ditempatkan Di Luar Negeri. https://bnp2tki.go.id diakses 28 Mei 2020.

Damarjati, Danu. 2017. Jokowi-Raja Salman Saksikan Penandatangan MoU Indonesia-Saudi. https://m.detik.com diakses 29 Mei 2020.

Fadhil, Abdul. 2013. Perbudakan Dan Buruh Migran Di Timur Tengah. Jurnal TAQAFIYYAT Volume 14, Nomor 1. Halaman : 162-178).

Fathun, Laode Muhamad. 2018. Geostrategi Kebijakan Luar Negeri Indonesia Di Era Jokowi Dalam Perspektif Kontruktivisme. Jurnal Islamic World and Politics Volume 2, Nomor 2. Haalaman : 318-344.

Fauzi, Gian Angga. 2017. Keterlibatan Indonesia Dalam Pra Mediasi Arab Saudi. ejurnal Ilmu Hubungan Internasional Volume 5, Nomor 4. Halaman : 1195-1210.

Ganewati, W. 2016. Politik Luar Negeri Indonesia di Tengah Pusaran Politik Domestik. Yogyakarta: Pustaka Pelajar kerjasama Pusat Penelitian Politik-LIPI.

Hikmawan, Emil dan Gustri Eni Putri. 2018. Upaya Aran Saudi Terhadap Organisasi Kerja Sama Islam Dalam Menyelesaikan Konflik Iran dan Arab Saudi Tahun 2013-2018. Jurnal Dauliyah Volume 3, Nomor 2. Halaman : 249-283. 
P-ISSN $2580-7781$

E-ISSN 2615 - 3238

Hutabarat, Reinhard F. 2017. Posisi Iran Dimata Indonesia. https://seword.com diakses pada 28 Mei 2020.

Hutapea, Rita Uli. 2017. Arab Saudi Eksekusi Mati 47 orang, Termasuk Ulama Syaih Terkemuka. https://news.detik.com diakses pada $27 \mathrm{Mei}$ 2020.

Isdah, Fadhylatur Rizqah. 2018. Hubungan Bilateral Arab Saudi-Indonesia di Era Pemerintahan Raja Salman-Joko Widodo. Skripsi Departemen Ilmu Hubungan Internasional: Fakultas Ilmu Sosial Dan Ilmu Politik Universitas Hasanuddin.

Karimah, Annisa. 2017. Kebijakan Indonesia Dalam Menengahi Konflik Arab Saudi-Iran Dalam Kasus Eksekusi Mati Nimr Al-Nimr. Skripsi Ilmu Hubungan Internasional: Fakultas ISIPOL Universitas Muhammadiyah Yogyakarta.

Kemenlu RI. 2016. Menlu Retno Sampaikan Pesan Damai Jokowi ke Iran dan Saudi. https://kemlu.go.id diakses pada 1 Mei 2020.

Kisihandi, Ferry. 2016. RI Ikut Cari Solusi. https://m.republika.co.id diakses pada 1 Mei 2020.

Kurniawan, Anto. 2016. Harga Minyak Dunia Melonjak Naik Terimbas Konflik Arab Saudi-Iran. https://eksib.sindonews.com diakses pada 27 Mei 2020.

Lukas, Andreas. 2017. Indonesia Tingkatkan Kerja Sama Bidang Perdadangan dengan Arab Saudi. https://kompas.com diakses pada 28 Mei 2020.

Mardiastuti, Aditya. 2016. Negara yang Putuskan Hubungan Diplomatik dengan Iran Bertambah. https://m.detik.com diakses pada 1 Mei 2020.

Mestika, Zed. 2014. Metode Penelitian Kepustakaan. Jakarta : Yayasan Pustaka Obor Indonesia.

Misrawi, Zuhairi. 2018. Konflik Arab Saudi vs Iran Harus Diakhiri. https://m.detik.com diakses pada 28 Mei 2020.

Patnistik, Egidius. 2016. Siapa Nimr al-Nirmr yang Menyulut Konflik Iran dan Arab Saudi?. https://amp.kompas.com diases 1 Mei 2020.

Rahmadani, Utami Nadirah. 2018. Kerjasama Indonesia-Iran dalam Sektor Energi Migas Periode 2015-2017. Skripsi Hubungan Internasional: Fakultas Ilmu Sosia Dan Ilmu Politik Universitas Pembangunan Nasional "Veteran" Jakarta.

Rifawan, Affabile. 2016. Dorong Indonesia menjadi mediator konflik Arab Saudi dan Iran. https://rapple.com diakses 28 Mei 2020.

Samosir, Hanna Azarya. 2016. Sejarah Panjang Perselisihan Arab Saudi dan Iran. https://m.cnnindonesia.com diakses 1 Mei 2020. 
P-ISSN $2580-7781$

E-ISSN 2615 - 3238

Sinaga, Rama Marito. 2018. Kepentingan Iran dan Indonesia Dalam Kerjasama Minya dan gas Tahun 2016. ejurnal Ilmu Hubungan Internasional, Volume 6, Nomor 3. Halaman: 1093-1106.

Undang-Undang Republik Indonesia Nomor 39 Tahun 2004 Tentang Penempatan dan Perlindungan Tenaga Kerja Indonesia di Luar Negeri.

Waskita, Ferdinand. 2015. Kepala BNP2TKI Beberkan Alasan WNI Cari Nafkah Ke Luar Negeri. https://tribunnews.com diakses pada $28 \mathrm{Mei}$ 2020 .

Wedhaswary, Inggried Dwi. 2016. Temui Jokowi, MUI Minta Indonesia Damaikan Iran dan Arab Saudi. https://kompas.com diakses 29 Mei 2020. 